Correspondence

Laurence Delhaes

I-delhaes@chru-lille.fr
Received 6 December 2006

Revised 23 May 2007

Accepted 25 May 2007

\section{Phylogenetic analysis of Trichophyton mentagrophytes human and animal isolates based on MnSOD and ITS sequence comparison}

\author{
Emilie Fréalle, ${ }^{1,2}$ Marion Rodrigue, ${ }^{1,2}$ Nausicaa Gantois, ${ }^{2}$ \\ Cécile-Marie Aliouat, ${ }^{2}$ Emmanuel Delaporte, ${ }^{3}$ Daniel Camus, ${ }^{1,2}$ \\ Eduardo Dei-Cas, ${ }^{1,2}$ Catherine Kauffmann-Lacroix, ${ }^{4}$ Jacques Guillot ${ }^{5}$ \\ and Laurence Delhaes ${ }^{1,2}$ \\ ${ }^{1}$ Département de Parasitologie-Mycologie, Faculté de Médecine, Pôle de Microbiologie, \\ CHRU de Lille, EA3609, Université de Lille 2, Lille, France \\ ${ }^{2}$ Laboratoire d'Ecologie du Parasitisme, Institut Pasteur de Lille, EA 3609, Université de Lille 2, Lille, \\ France \\ ${ }^{3}$ Clinique Dermatologique, CHRU de Lille, Université de Lille 2, Lille, France \\ ${ }^{4}$ Service de Parasitologie Mycologie, CHRU de Poitiers, Poitiers, France \\ ${ }^{5}$ Service de Parasitologie Mycologie, UMR 956 INRA, Ecole Nationale Vétérinaire d'Alfort, \\ Maisons-Alfort, France
}

\begin{abstract}
Dermatophytes are keratinophilic fungi able to infect keratinized tissues of human or animal origin. Among them, Trichophyton mentagrophytes is known to be a species complex composed of several species or variants, which occur in both human and animals. Since the T. mentagrophytes complex includes both anthropophilic and zoophilic pathogens, accurate molecular identification is a critical issue for comprehensive understanding of the clinical and epidemiological implications of the genetic heterogeneity of this complex. Here, $41 \mathrm{~T}$. mentagrophytes isolates from either human patients (14 isolates) or animals (27 isolates) with dermatophytosis were prospectively isolated by culture and identified on morphological bases at the University Hospital Centres of Lille and Poitiers, and the Veterinary School of Alfort, respectively. The isolates were differentiated by DNA sequencing of the variable internal transcribed spacer (ITS) regions flanking the 5.8S rDNA, and of the housekeeping gene encoding the manganese-containing superoxide dismutase (MnSOD), an enzyme which is involved in defence against oxidative stress and has previously provided interesting insight into both fungal taxonomy and phylogeny. ITS1-ITS2 regions and MnSOD sequences successfully differentiate between members of the T. mentagrophytes complex and the related species Trichophyton rubrum. Whatever the phylogenetic marker used, members of this complex were classified into two major clades exhibiting a similar topology, with a higher variability when the ITS marker was used. Relationships between ITS/MnSOD sequences and host origin, clinical pattern and phenotypic characteristics (macroscopic and microscopic morphologies) were analysed.
\end{abstract}

\section{INTRODUCTION}

Dermatophytes are keratinophilic fungi able to infect keratinized tissues of human or animal origin, leading to infections that are mainly restricted to the corneocytes of the skin, hair and nails. These filamentous fungi are usually

Abbreviations: ITS, internal transcribed spacer; ML, maximum likelihood; MnSOD, manganese-containing superoxide dismutase; NJ, neighbourjoining.

The GenBank/EMBL/DDBJ accession numbers for the MnSOD and ITS sequences determined in this work are given in the text and Fig. 1. identified on the basis of clinical features and isolation patterns together with conidial morphology, and sometimes with physiological characters, such as the hair perforation and urease tests. In some cases, morphological identification can be difficult or uncertain because there is considerable variation and pleomorphism among isolates of the same species. In the last decade, genotyping approaches have proven to be useful for solving problems of dermatophyte taxonomy, as well as enhancing the reliability and speed of dermatophytosis diagnosis (De Hoog et al., 1998; Faggi et al., 2001, 2002; Graser et al., 
2006; Jousson et al., 2004; Kano et al., 2003; Kardjeva et al., 2006; Liu et al., 2000; Mochizuki et al., 1990, 1999; Ninet et al., 2003; Weitzman \& Summerbell, 1995).

Members of the Trichophyton mentagrophytes species complex are common agents of human dermatophytosis in Europe (Kardjeva et al., 2006; Monod et al., 2002), invading skin layers (Kaufman et al., 2004) and causing superficial infections, such as tinea pedis or athlete's foot (De Hoog et al., 1998; Weitzman \& Summerbell, 1995), with an increased incidence since 1965 (Kardjeva et al., 2006). The species included in this anthropo-zoophilic complex, which were first defined on the basis of morphological features and mating-type studies, have more recently been investigated using molecular methods, revealing an organization more complex than expected. These molecular approaches have been based primarily on the G $+\mathrm{C}$ content of chromosomal DNA (Davison et al., 1980), total DNA homology (Davison \& Mackenzie, 1984), restriction fragment length polymorphism analysis of mitochondrial DNA (mtDNA) (Mochizuki et al., 1990, 1996), arbitrarily primed PCR (AP-PCR) (Liu et al., 2000), random amplification of polymorphic DNA (RAPD) analysis (Kac et al., 1999; Liu et al., 1997; Mochizuki et al., 1997) and PCR fingerprinting (Faggi et al., 2001; Graser et al., 1999b). More recently, sequence analysis of the rDNA regions (Graser et al., 1999a; Harmsen et al., 1995; Makimura et al., 1998, 1999; Mochizuki et al., 1999, 2003) and, in particular, analysis of internal transcribed spacer (ITS) regions (Graser et al., 1999a; Makimura et al., 1998, 1999; Mochizuki et al., 1999), which appeared more suitable than the gene coding for the small-subunit rRNA (18S rRNA) (Harmsen et al., 1995), were used successfully to evaluate the phylogenetic relationships within the $T$. mentagrophytes complex. These accurate molecular studies emerged as a critical issue for comprehensive understanding of the clinical and epidemiological implications of the genetic heterogeneity of T. mentagrophytes and resulted in the re-establishment of three if not four species: Trichophyton interdigitale close to the teleomorph Arthroderma vanbreuseghemii, $T$. mentagrophytes close to the teleomorph A. simii, and T. erinacei, plus another Trichophyon anamorph, both close to the teleomorph $A$. benhamiae, which includes both European-American and African races (Graser et al. 1999b; Probst et al., 2002; Takahashi et al., 2003; Nenoff et al., 2007). Among these four species, two were rooted in typification, according to the criteria of the International Code of Botanical Nomenclature: T. mentagrophytes (strain CBS 318.56) and T. interdigitale (strain CBS 428.63) (Graser et al., 1999b).

Molecular analysis using protein-encoding gene sequence approaches are poorly developed among the genera of dermatophyte species. The chitin synthase 1 gene and fungalysin gene family are the unique protein-encoding genes that have been sequenced to provide information for the identification of Trichophyton species and the understanding of their evolution (Jousson et al., 2004; Kano et al.,
1998, 2003). In the present study, we attempted to evaluate the relationships between members of the $T$. mentagrophytes complex isolated from both human beings and animals using a housekeeping gene encoding the manganese-containing superoxide dismutase (MnSOD), which is involved in cell defence against endogenous and exogenous reactive oxygen species, and which has previously provided interesting insights into both fungal taxonomy, contributing to the differentiation of Pneumocystis species (Denis et al., 2000), and phylogeny, leading to a complex evolutionary scenario of the MnSOD gene with several gene duplication events (Fréalle et al., 2005, 2006).

As the T. mentagrophytes complex includes both anthropophilic and zoophilic pathogens, we included both human and animal isolates (natural and occasional hosts), with the aim of analysing their phylogenetic distribution within the four species of the T. mentagrophytes complex. Using this phylogenetic distribution, we explored the potential association of each species with specific hosts, and with characteristic and stable morphological features, trying to get reliable criteria for the routine identification of these species. The polymorphism of the ITS1 and ITS2 non-coding regions flanking the DNA sequence encoding the 5.8S rRNA was also analysed and compared with the MnSOD sequence results.

\section{METHODS}

Fungal strains. Forty-one T. mentagrophytes isolates from either human patients with dermatophytosis (14 isolates) or animals with or without visible lesions (27 isolates) were prospectively isolated by culture and identified on the basis of their morphological features at the University Hospital Centres of Lille and Poitiers, and the Veterinary School of Alfort, respectively, from May 2002 to March 2004. These isolates were compared to the T. mentagrophytes neotype (CBS 318.56), and to the following three strains: T. interdigitale (TMC-42, Lille Pasteur Institute), a zoophilic strain of T. interdigitale (TMC-43, Lille Pasteur Institute) and T. erinacei (TMC-44, Lille Pasteur Institute), for which the species identification was confirmed at the Pasteur Institute of Paris Mycology Department. These three strains (TMC-42-44) were used as standard strains in this study. T. interdigitale TMC-42, T. interdigitale TMC-43, and one representative of every novel genotype were deposited in the CBS collection. Collection numbers are indicated in Table 1. All the T. mentagrophytes isolates and strains were analysed at the molecular level using $T$. rubrum TR-104 (Lille Pasteur Institute) as an outgroup.

All strains were grown at $30{ }^{\circ} \mathrm{C}$ on Sabouraud's agar medium with kanamycin and with kanamycin plus cycloheximide for 3 weeks. They were identified on the basis of microscopy and colony characteristics and were classified using the following criteria: (i) clinical criteria (body localization, associated or not with clinical signs or symptoms of dermatophytosis), (ii) cultural aspects (texture, front and reverse colour of the colonies), and (iii) microscopic features (subspherical or clavate microconidia, macroconidia, spiral hyphae, and dense branchlets at right angles) (Graser et al., 1999b; Mochizuki et al., 1996, 2003; Ninet et al., 2003). Morphological data for the isolates, and their origins, are listed in Table 1.

DNA extraction. DNA was extracted from a small amount of mycelium grown on Sabouraud dextrose agar by a rapid preparation method (Fréalle et al., 2005, 2006). Each isolate was treated separately, 
Table 1. Clinical and culture data of the isolates of Trichophyton spp. used in the study

\begin{tabular}{|c|c|c|c|c|c|c|c|}
\hline \multirow[t]{4}{*}{ TMC or CBS no.* } & \multicolumn{2}{|c|}{ General and clinical data } & \multicolumn{5}{|c|}{ Macroscopic and microscopic features of Sabouraud agar culture } \\
\hline & \multirow[t]{3}{*}{ Origin $\dagger$} & \multirow{3}{*}{$\begin{array}{l}\text { Source (sex, age, } \\
\text { symptomatology) } \ddagger\end{array}$} & \multirow[t]{3}{*}{ Colony morphology $\S$} & \multicolumn{4}{|c|}{ Microscopic features\| } \\
\hline & & & & \multicolumn{2}{|c|}{ Conidia criteria } & \multicolumn{2}{|c|}{ Mycelium criteria } \\
\hline & & & & Microconidia & Macroconidia & $\begin{array}{l}\text { Spiral } \\
\text { hyphae }\end{array}$ & $\begin{array}{c}\text { Branchlets at } \\
\text { right angles }\end{array}$ \\
\hline \multicolumn{8}{|l|}{ Clade I } \\
\hline \multicolumn{8}{|l|}{ Subclade 1, Group A } \\
\hline $\begin{array}{l}\text { TMC-3 }(\mathrm{H}) \\
=\text { CBS } 121072\end{array}$ & Lille & $\mathrm{F}, 15 \mathrm{y}$, Tinea pedis & $\begin{array}{l}\text { Downy with yellow-orange } \\
\text { to brown reverse }\end{array}$ & Subspherical & - & - & $-1+$ \\
\hline TMC-6 (H) & Lille & $\begin{array}{l}\text { M, } 41 \text { y, } \\
\text { Onychomycosis }\end{array}$ & $\begin{array}{l}\text { Powdery with yellow to } \\
\text { orange reverse }\end{array}$ & $\begin{array}{l}\text { Subspherical to } \\
\text { ovoid }\end{array}$ & - & - & ++ \\
\hline TMC-10 (H) & Lille & F, $37 \mathrm{y}$, Skin & $\begin{array}{l}\text { Powdery with yellow to } \\
\text { orange reverse }\end{array}$ & $\begin{array}{l}\text { Subspherical to } \\
\text { ovoid }\end{array}$ & - & +++ & $-1+$ \\
\hline TMC-11 (H) & Poitiers & $\mathrm{F}, 14 \mathrm{y}$, Tinea pedis & $\begin{array}{l}\text { Downy with yellow-orange } \\
\text { to brown reverse }\end{array}$ & Subspherical & - & ++ & - \\
\hline TMC-12(H) & Poitiers & M, $68 \mathrm{y}$, Tinea pedis & $\begin{array}{l}\text { Downy to powdery with } \\
\text { yellow-orange reverse }\end{array}$ & Subspherical & + & ++ & $-1+$ \\
\hline TMC-13 (H) & Poitiers & $\begin{array}{l}\text { M, } 39 \text { y, } \\
\text { Onychomycosis }\end{array}$ & $\begin{array}{l}\text { Downy to powdery with } \\
\text { yellow-orange reverse }\end{array}$ & Subspherical & + & ++ & - \\
\hline TMC-14 (H) & Poitiers & M, $78 \mathrm{y}$, Tinea pedis & $\begin{array}{l}\text { Downy to powdery with } \\
\text { yellow-orange reverse }\end{array}$ & ND & ND & ND & ND \\
\hline TMC-18 (A) & ENVA & M, Guinea pig & $\begin{array}{l}\text { Powdery with brown to } \\
\text { reddish-purple reverse }\end{array}$ & Subspherical & ++ & +++ & $-1+$ \\
\hline TMC-25 (A) & ENVA & M, 3 m, Guinea pig & $\begin{array}{l}\text { Powdery with orange to } \\
\text { brown reverse }\end{array}$ & Subspherical & - & - & $-1+$ \\
\hline $\begin{array}{l}\text { TMC-7 }(\mathrm{H}) \\
=\text { CBS } 121069\end{array}$ & Lille & $\begin{array}{l}\text { M, } 56 \text { y, Tinea cor- } \\
\text { poris/inflammatory } \\
\text { lesion }\end{array}$ & $\begin{array}{l}\text { Powdery with brown to } \\
\text { reddish-purple reverse }\end{array}$ & Subspherical & ++ & + & - \\
\hline TMC-40 (A) & ENVA & F, 6 y, Dog & $\begin{array}{l}\text { Downy with yellow to } \\
\text { orange reverse }\end{array}$ & Subspherical & - & +++ & - \\
\hline TMC-41 (A) & ENVA & F, 2 y, Pig & $\begin{array}{l}\text { Powdery with brown to } \\
\text { reddish-purple reverse }\end{array}$ & $\begin{array}{l}\text { Subspherical } \\
\text { to ovoid }\end{array}$ & +++ & +++ & + \\
\hline \multicolumn{8}{|l|}{ Subclade 1, Group B } \\
\hline TMC-32 (A) & ENVA & Chinchilla & $\begin{array}{l}\text { Downy with yellow to } \\
\text { orange reverse }\end{array}$ & Subspherical & + & - & ++ \\
\hline $\begin{array}{l}\text { TMC-33 (A) } \\
=\text { CBS } 121065\end{array}$ & ENVA & Chinchilla & $\begin{array}{l}\text { Powdery with orange to } \\
\text { brown reverse }\end{array}$ & Subspherical & - & - & ++ \\
\hline TMC-35 (A) & ENVA & Chinchilla & $\begin{array}{l}\text { Powdery to downy with } \\
\text { brown to reddish-purple } \\
\text { reverse }\end{array}$ & Subspherical & - & - & - \\
\hline $\begin{array}{l}\text { TMC-36 (A) } \\
=\text { CBS } 121064\end{array}$ & ENVA & Mouse & $\begin{array}{l}\text { Powdery with orange to } \\
\text { brown reverse }\end{array}$ & Subspherical & - & ++ & - \\
\hline TMC-37 (A) & ENVA & F, 1 y, Mouse & $\begin{array}{l}\text { Powdery with orange to } \\
\text { brown reverse }\end{array}$ & Subspherical & - & +++ & - \\
\hline TMC-38 (A) & ENVA & Mouse & $\begin{array}{l}\text { Powdery with orange to } \\
\text { brown reverse }\end{array}$ & Subspherical & - & - & - \\
\hline $\begin{array}{l}\text { TMC-4 }(\mathrm{H}) \\
=\text { CBS } 121070\end{array}$ & Lille & $\begin{array}{l}\mathrm{F}, 18 \mathrm{y} \text {, Tinea } \\
\text { corporis }\end{array}$ & $\begin{array}{l}\text { Powdery with yellow-orange } \\
\text { to brown reverse }\end{array}$ & $\begin{array}{l}\text { Subspherical } \\
\text { to ovoid }\end{array}$ & - & +++ & $-1+$ \\
\hline TMC-8 (H) & Lille & $\begin{array}{l}\text { M, } 12 \mathrm{y} \\
\text { Skin/inflammatory } \\
\text { lesion }\end{array}$ & Powdery with brown reverse & Subspherical & ++ & ++ & - \\
\hline
\end{tabular}


Table 1. cont.

\begin{tabular}{|c|c|c|c|c|c|c|c|}
\hline \multirow[t]{4}{*}{ TMC or CBS no.* } & \multicolumn{2}{|c|}{ General and clinical data } & \multicolumn{5}{|c|}{ Macroscopic and microscopic features of Sabouraud agar culture } \\
\hline & \multirow[t]{3}{*}{ Origin $\dagger$} & \multirow{3}{*}{$\begin{array}{l}\text { Source (sex, age, } \\
\text { symptomatology) } \ddagger\end{array}$} & \multirow[t]{3}{*}{ Colony morphology } & \multicolumn{4}{|c|}{ Microscopic features $\|$} \\
\hline & & & & \multicolumn{2}{|c|}{ Conidia criteria } & \multicolumn{2}{|c|}{ Mycelium criteria } \\
\hline & & & & Microconidia & Macroconidia & $\begin{array}{c}\text { Spiral } \\
\text { hyphae }\end{array}$ & $\begin{array}{l}\text { Branchlets at } \\
\text { right angles }\end{array}$ \\
\hline \multicolumn{8}{|l|}{ Clade II } \\
\hline TMC-1 (H) & Lille & $\mathrm{F}, 7 \mathrm{y}$, Skin of ear & $\begin{array}{l}\text { Downy with yellow-orange } \\
\text { to brown reverse }\end{array}$ & Clavate & - & - & ++ \\
\hline TMC-2 (H) & Lille & $\begin{array}{l}\text { M, } 11 \mathrm{y}, \text { Skin/ } \\
\text { inflammatory lesion }\end{array}$ & $\begin{array}{l}\text { Powdery with yellow to } \\
\text { orange reverse }\end{array}$ & Clavate & - & - & ++ \\
\hline TMC-5 (H) & Lille & $\begin{array}{c}\mathrm{F}, 6 \mathrm{y} \text {, Tinea corporis/ } \\
\text { inflammatory lesion }\end{array}$ & $\begin{array}{l}\text { Powdery with brown to } \\
\text { reddish-purple reverse }\end{array}$ & $\begin{array}{l}\text { Subspherical } \\
\text { to ovoid }\end{array}$ & - & $-1+$ & +++ \\
\hline TMC-9 (H) & Lille & $\begin{array}{l}\text { F, } 10 \mathrm{y} \text {, Tinea capitis/ } \\
\text { inflammatory lesion }\end{array}$ & $\begin{array}{l}\text { Downy to powdery with } \\
\text { yellow to orange reverse }\end{array}$ & $\begin{array}{l}\text { Subspherical } \\
\text { to ovoid }\end{array}$ & - & - & ++ \\
\hline $\begin{array}{l}\text { TMC-15 (A) } \\
=\text { CBS } 121071\end{array}$ & ENVA & M, Guinea pig & $\begin{array}{l}\text { Downy to powdery with } \\
\text { brown to reddish-purple } \\
\text { reverse }\end{array}$ & $\begin{array}{l}\text { Subspherical } \\
\text { to ovoid }\end{array}$ & - & - & +++ \\
\hline TMC-16 (A) & ENVA & M, Guinea pig & $\begin{array}{l}\text { Downy to powdery with } \\
\text { brown to reddish-purple } \\
\text { reverse }\end{array}$ & Subspherical & - & - & ++ \\
\hline TMC-17 (A) & ENVA & F, Guinea pig & $\begin{array}{l}\text { Downy to powdery with } \\
\text { brown to reddish-purple } \\
\text { reverse }\end{array}$ & $\begin{array}{l}\text { Subspherical } \\
\text { to ovoid }\end{array}$ & - & - & +++ \\
\hline TMC-19 (A) & ENVA & F, Guinea pig & $\begin{array}{l}\text { Powdery with brown to } \\
\text { reddish-purple reverse }\end{array}$ & $\begin{array}{l}\text { Subspherical } \\
\text { to ovoid }\end{array}$ & - & + & + \\
\hline TMC-20 (A) & ENVA & $\mathrm{F}, 2 \mathrm{~m}$, Guinea pig & $\begin{array}{l}\text { Downy to powdery with } \\
\text { brown to reddish-purple } \\
\text { reverse }\end{array}$ & $\begin{array}{l}\text { Subspherical } \\
\text { to ovoid }\end{array}$ & - & - & +++ \\
\hline TMC-21 (A) & ENVA & $\mathrm{F}, 3 \mathrm{~m}$, Guinea pig & $\begin{array}{l}\text { Powdery with brown to } \\
\text { reddish-purple reverse }\end{array}$ & $\begin{array}{l}\text { Subspherical } \\
\text { to ovoid }\end{array}$ & - & + & - \\
\hline TMC-22 (A) & ENVA & F, 3 y, Guinea pig & $\begin{array}{l}\text { Powdery with brown to } \\
\text { reddish-purple reverse }\end{array}$ & $\begin{array}{l}\text { Subspherical } \\
\text { to ovoid }\end{array}$ & - & - & +++ \\
\hline TMC-23 (A) & ENVA & Guinea pig & $\begin{array}{l}\text { Downy to powdery with } \\
\text { brown to reddish-purple } \\
\text { reverse }\end{array}$ & $\begin{array}{l}\text { Subspherical } \\
\text { to ovoid }\end{array}$ & - & - & +++ \\
\hline TMC-24 (A) & ENVA & M, Guinea pig & $\begin{array}{l}\text { Downy to powdery with } \\
\text { brown to reddish-purple } \\
\text { reverse }\end{array}$ & $\begin{array}{l}\text { Subspherical } \\
\text { to ovoid }\end{array}$ & - & - & +++ \\
\hline TMC-26 (A) & ENVA & M, 3 m, Rabbit & $\begin{array}{l}\text { Downy to powdery with } \\
\text { orange reverse }\end{array}$ & $\begin{array}{l}\text { Subspherical } \\
\text { to ovoid }\end{array}$ & - & - & +++ \\
\hline TMC-27 (A) & ENVA & M, 3 m, Rabbit & $\begin{array}{l}\text { Downy to powdery with } \\
\text { brown to reddish-purple } \\
\text { reverse }\end{array}$ & $\begin{array}{l}\text { Subspherical } \\
\text { to ovoid }\end{array}$ & - & + & ++ \\
\hline TMC-28 (A) & ENVA & F, 3 m, Rabbit & $\begin{array}{l}\text { Downy to powdery with } \\
\text { yellow to orange reverse }\end{array}$ & $\mathrm{ND}$ & ND & ND & ND \\
\hline TMC-29 (A) & ENVA & M, 4 m, Rabbit & $\begin{array}{l}\text { Downy with brown to } \\
\text { reddish-purple reverse }\end{array}$ & Subspherical & - & - & ++ \\
\hline TMC-30 (A) & ENVA & Rabbit & $\begin{array}{l}\text { Powdery with orange to } \\
\text { brown reverse }\end{array}$ & Clavate & +++ & - & +++ \\
\hline TMC-31 (A) & ENVA & F, 4 m, Rabbit & $\begin{array}{l}\text { Downy with brown to } \\
\text { reddish-purple reverse }\end{array}$ & $\begin{array}{l}\text { Subspherical } \\
\text { to ovoid }\end{array}$ & + & - & +++ \\
\hline $\begin{array}{l}\text { TMC-34 (A) } \\
=\text { CBS } 121067\end{array}$ & ENVA & Chinchilla & $\begin{array}{l}\text { Downy with yellow to } \\
\text { orange reverse }\end{array}$ & Subspherical & - & - & - \\
\hline
\end{tabular}


Table 1. cont.

\begin{tabular}{|c|c|c|c|c|c|c|c|}
\hline \multirow[t]{4}{*}{ TMC or CBS no.* } & \multicolumn{2}{|c|}{ General and clinical data } & \multicolumn{5}{|c|}{ Macroscopic and microscopic features of Sabouraud agar culture } \\
\hline & \multirow[t]{3}{*}{ Origin $\dagger$} & \multirow{3}{*}{$\begin{array}{l}\text { Source (sex, age, } \\
\text { symptomatology) } \ddagger\end{array}$} & \multirow[t]{3}{*}{ Colony morphology $\S$} & \multicolumn{4}{|c|}{ Microscopic features $\|$} \\
\hline & & & & \multicolumn{2}{|c|}{ Conidia criteria } & \multicolumn{2}{|c|}{ Mycelium criteria } \\
\hline & & & & Microconidia & Macroconidia & $\begin{array}{c}\text { Spiral } \\
\text { hyphae }\end{array}$ & $\begin{array}{l}\text { Branchlets at } \\
\text { right angles }\end{array}$ \\
\hline TMC-39 (A) & ENVA & M, 2 y, Dog & $\begin{array}{l}\text { Downy to powdery with } \\
\text { brown to reddish-purple } \\
\text { reverse }\end{array}$ & $\begin{array}{l}\text { Subspherical } \\
\text { to ovoid }\end{array}$ & - & + & +++ \\
\hline \multicolumn{8}{|c|}{ Standard strains identified at Pasteur Institute of Paris } \\
\hline $\begin{array}{l}\text { TMC-42: } T \text {. } \\
\text { interdigitale } \\
=\text { CBS } 121066\end{array}$ & & Human & $\begin{array}{l}\text { Downy with } \\
\text { yellow-orange to brown } \\
\text { reverse }\end{array}$ & Subspherical & - & ++ & $-1+$ \\
\hline $\begin{array}{l}\text { TMC-43: zoophilic } \\
\text { strain of } T \text {. } \\
\text { interdigitale } \\
=\text { CBS } 121068\end{array}$ & & Unspecified & $\begin{array}{l}\text { Powdery with brown to } \\
\text { reddish-purple reverse }\end{array}$ & Subspherical & $+1++$ & ++ & - \\
\hline TMC-44: T. erinacei & & Unspecified & $\begin{array}{l}\text { Downy to powdery with } \\
\text { yellow to orange reverse }\end{array}$ & Clavate & +++ & - & +++ \\
\hline
\end{tabular}

${ }^{\star}$ A TMC number was attributed to each T. mentagrophytes isolate included in our study. T. interdigitale (TMC-42), T. interdigitale zoophilic strain (TMC-43), and one representative of every genotype were deposited in the CBS Collection. CBS numbers of these isolates are indicated in bold. $(\mathrm{H})$, human isolates; (A), animal isolates.

$\dagger$ ENVA, Ecole Nationale Vétérinaire d'Alfort.

$\ddagger \mathrm{M}$, male; F, female. When host age is known: $y$, years; $\mathrm{m}$, months.

$\S$ Morphology on Sabouraud agar medium incubated at $30{ }^{\circ} \mathrm{C}$ for 3 weeks.

IIAbsence or presence of macroconidia, spiral hyphae, and mycelium branchlets at right angles were noted as follows: absence $(-)$, few $(+)$, moderate $(++)$ or abundant $(+++)$. ND, Not determined.

under a laminar-airflow hood to avoid contamination. Briefly, fresh mycelium (approx. $1 \mathrm{~cm}^{2}$ ) was collected and put into an Eppendorf tube containing $1 \mathrm{ml}$ distilled water. After centrifugation at 8000 r.p.m. for $2 \mathrm{~min}$, DNA was extracted according to the protocol of the QIAamp DNA minikit column (Qiagen), and eluted with $200 \mu \mathrm{l}$ distilled water.

Sequencing of the MnSOD and ITS loci. A 420 or 421 bp fragment of the MnSOD gene was amplified by PCR using the following pair of specific primers: Tm-SODf (5'-CATCATCAAACCTACGTCAAC-3') and Tm-SODr ( $5^{\prime}$-TAGTAGGCGTGCTCCCAGG-3'), designed using the T. mentagrophytes partial MnSOD sequence (GenBank accession no. AY625498) determined in a previous study (Fréalle et al., 2005, 2006). Amplification reactions were performed in a final volume of $50 \mu \mathrm{l}$ containing $6 \mu \mathrm{l}$ template DNA, $5 \mu \mathrm{l}$ reaction buffer $(10 \times)$, $1.5 \mu \mathrm{M} \mathrm{MgCl}_{2}, 200 \mu \mathrm{M}$ of each dNTP, $0.8 \mu \mathrm{M}$ of each primer and 2 units Taq polymerase (AmpliTaq Gold, Roche Molecular Biochemicals). The PCR cycling protocol was performed in a PTC200 DNA Engine (MJ Research) as follows: one initial denaturation step of 3 min at $94{ }^{\circ} \mathrm{C}$, followed by 40 cycles consisting of denaturation for $1 \mathrm{~min}$ at $94{ }^{\circ} \mathrm{C}$, annealing for $1 \mathrm{~min}$ at $47^{\circ} \mathrm{C}$ and extension for $1 \mathrm{~min}$ at $72{ }^{\circ} \mathrm{C}$, followed by a final extension for $10 \mathrm{~min}$ at $72{ }^{\circ} \mathrm{C}$.

The ribosomal ITS regions were amplified according to published methods (Graser et al., 1999a, b). Briefly, amplification reactions were performed in a final volume of $100 \mu$ containing $6 \mu$ template DNA, $10 \mu \mathrm{l}$ reaction buffer, $1.5 \mu \mathrm{M} \mathrm{MgCl}_{2}, 200 \mu \mathrm{M}$ of each dNTP, $0.8 \mu \mathrm{M}$ of each universal primer ITS1 (5' ${ }^{\prime}$ TCCGTAGGTGAACCTGCGG-3') and ITS4 (5'-TCCTCCGCTTATTGATATGC-3') and 3 units Taq polymerase (AmpliTaq Gold, Roche Molecular Biochemicals). Each PCR mixture was heated to $94{ }^{\circ} \mathrm{C}$ for $3 \mathrm{~min}$, and the PCR was then performed under the following conditions: 20 cycles consisting of $94{ }^{\circ} \mathrm{C}$ for $35 \mathrm{~s}, 54{ }^{\circ} \mathrm{C}$ for $55 \mathrm{~s}, 72{ }^{\circ} \mathrm{C}$ for $45 \mathrm{~s}$, increasing the extension time by $4 \mathrm{~s}$ on each cycle, and 10 cycles consisting of $94{ }^{\circ} \mathrm{C}$ for $45 \mathrm{~s}$, $54{ }^{\circ} \mathrm{C}$ for $55 \mathrm{~s}, 72{ }^{\circ} \mathrm{C}$ for $2 \mathrm{~min}$, increasing the extension time by $4 \mathrm{~s}$ on each cycle, with a final extension at $72{ }^{\circ} \mathrm{C}$ for $6 \mathrm{~min}$.

Two per cent agarose gel electrophoresis was performed to examine the quality of the PCR products. Forty microlitres of each PCR product was purified with the QIAEX II Gel Extraction kit (Qiagen). Final DNA concentration was evaluated by measuring $A_{260}$. Both strands of purified PCR products $(5-10 \mu \mathrm{l} ; 700 \mathrm{ng})$ were directly sequenced by using Big Dye Terminator Cycle Sequencing kit (Applied Biosystems) with primers Tm-SODf/Tm-SODr or ITS1/ ITS4 depending on the targeted gene (MnSOD gene or ITS region respectively). Sequences were run on an automated ABI Prism 377 DNA sequencer (Applied Biosystems), according to the manufacturer's instructions. For each PCR product, a consensus nucleotide sequence was determined using BioEdit software (Tippmann, 2004) and significant sequence identity with known fungal MnSOD gene or ITS region sequences was displayed by using the BLAST standard nucleotide-nucleotide local alignment search tool (NCBI; http:/ www.ncbi.nlm.nih.gov/BLAST/). T. rubrum isolate TR-104 showed complete sequence identity to T. rubrum CBS 392.58 at the ITS region locus (sequence accession number Z97993; Graser et al., 1999a).

Determination of the deduced amino acid MnSOD sequences. Amino acid sequences were deduced from each MnSOD nucleotide 
consensus sequence. The T. mentagrophytes MnSOD sequences, as well as the T. rubrum MnSOD sequence, had an open reading frame composed of two exons and one intron whose position had been previously identified by canonical 5' (GT) and 3' (AG) intron/exon boundaries (Parker \& Patterson, 1987), and confirmed by RT-PCR (Fréalle et al., 2006).

Phylogenetic analysis. The partial MnSOD gene sequences and the corresponding deduced amino acid sequences were aligned using CLUSTAL $\mathrm{W}$ as implemented in the BioEdit program (Tippmann, 2004). Using the same program, ITS sequences of the same isolates were aligned with 24 ITS sequences of the T. mentagrophytes complex and T. rubrum retrieved from GenBank. Accession numbers of the sequences included in the ITS dataset are listed in Fig. 1.

The phylogenetic trees were constructed by the neighbour-joining (NJ) and maximum-likelihood (ML) methods, using the PHYLIP package (Felsenstein, 1997). The reliability of internal branches was assessed using the bootstrap method implemented in the PHYLIP program, with 1000 (NJ) and 100 (ML) replicates. Phylogenetic trees were rooted with T. rubrum as an outgroup, and edited using TreeView (Page, 1996).

Nucleotide sequence accession numbers. The MnSOD and ITS region sequences determined in this study were submitted to the GenBank nucleotide sequence database. The ITS region sequence accession numbers (DQ786656 to DQ786699) are indicated in Fig. 1. The MnSOD sequence accession numbers are DQ786700 to DQ786744: DQ786700 to DQ786740 for isolates TMC-1 to TMC41, DQ786741 for the T. interdigitale standard strain (TMC-42), DQ786742 for the zoophilic strain of $T$. interdigitale (TMC-43), DQ786743 for the T. erinacei standard strain (TMC-44), EF614237 for T. mentagrophytes strain CBS 318.56, and DQ786744 for the isolate of T. rubrum (TR-104).

\section{RESULTS AND DISCUSSION}

\section{Epidemiology and ecology}

Considering our human isolates $(n=14)$, the sex distribution ratio $(\mathrm{M} / \mathrm{F})$ was 1.1, lower than found in a previous study (Contet-Audonneau et al., 2001); the age population distribution, with a majority of 10-19 year-old patients, was in accordance with previous results (ContetAudonneau et al., 2001). We found a majority of glabrous skin manifestations (tinea corporis) and athlete's foot (tinea pedis), in accordance with previous reports in Europe (Nowicki et al., 1994) (Table 1).

The hosts of our animal isolate sample $(n=27)$ were mainly rodents $(n=18)$ : mice, guinea pigs and chinchillas. This host population is mainly composed of exotic pets that have been recently introduced into Europe, including France, influencing the epidemiology of the T. mentagrophytes complex in these regions (Summerbell et al., 2002; Weitzman \& Summerbell, 1995) (Table 1).

\section{Analysis of MnSOD sequences}

All the nucleotide sequences analysed in this study exhibited a high degree of identity $(>94.5 \%)$ with genes encoding T. mentagrophytes tetrameric MnSOD sequences available in databases (Fréalle et al., 2006). Fragment length was 420 or $421 \mathrm{bp}$, with an open reading frame composed of two exons separated by a 58 or 59 bp intron.

Based on BLAST searches at the NCBI website (http:/www. ncbi.nlm.nih.gov/BLAST/), the corresponding deduced SOD amino acid sequences exhibited a higher degree of identity to the tetrameric MnSODs than to the other types of SODs, suggesting that they all belong to the class of tetrameric MnSODs ( $80 \%$ identity with the MnSOD amino acid sequence of Coccidioides immitis: EAS36233). Although our fungal SOD protein sequences were partial, they displayed almost all features of tetrameric MnSODs, including the residue Phe ${ }^{27}$ systematically encountered in tetramers and never in dimers, and the manganese-specific residues $\mathrm{Gly}^{30}$, $\mathrm{Gly}^{31}, \mathrm{Phe}^{38}, \mathrm{Gln}^{107}$ and $\mathrm{Asp}^{108}$ (numbering as in sequences submitted to GenBank; Parker \& Blake, 1988). When alignment was performed using CLUSTAL W, we identified 29 mutations (including one insertion/deletion) at the MnSOD locus for isolates restricted to genotypes II, III (isolate TMC34), IV (T. erinacei TMC-44) and V (T. mentagrophytes neotype CBS 318.56) (Table 2). Most nucleotide mutations were localized within the intron, or were exon silent substitutions. Only two non-synonymous mutations (amino acid residues at positions 70 and 95, Table 2) were found in isolates of MnSOD genotypes II, III, IV and V.

\section{Phylogenetic analysis}

Phylogenetic analysis was performed for both the MnSOD and ITS datasets (Fig. 1). All sites of the MnSOD nucleotide and protein sequences could be unambiguously aligned, yielding 421 nucleotide positions and 120 amino acid sites respectively. The ITS sequences included mainly ITS1 and ITS2 regions, and the 5.8S rDNA gene. Regions of ambiguous alignment were removed, yielding 637 nucleotide sites for the dataset analysis. Given the low variability observed among MnSOD sequences, the MnSOD phylogenetic study resulted in only five groups, corresponding to the five genotypes described in Table 2 and shown in the ITS tree (Fig. 1).

In accordance with previous results (Graser et al., 1999a, b; Makimura et al., 1998), members of the T. mentagrophytes complex fell into two major closely related clades, emerging at a considerable distance from T. rubrum, which was used as an outgroup. The T. mentagrophytes complex showed marked genetic heterogeneity, as previously described (Graser et al., 1999a, b; Makimura et al., 1998), and the topology resulting from ITS sequences showed higher variability than that based on MnSOD sequence polymorphism (up to $10.6 \%$ for ITS vs $5.5 \%$ for MnSOD nucleotide sequences).

The T. mentagrophytes complex isolates and strains fell into five groups (indicated as 'MnSOD genotype' in Fig. 1) when MnSOD DNA sequences were analysed. The MnSOD sequence differences between isolates and/or the standard strains were generally single-nucleotide polymorphisms. Similar findings were made previously when other target 


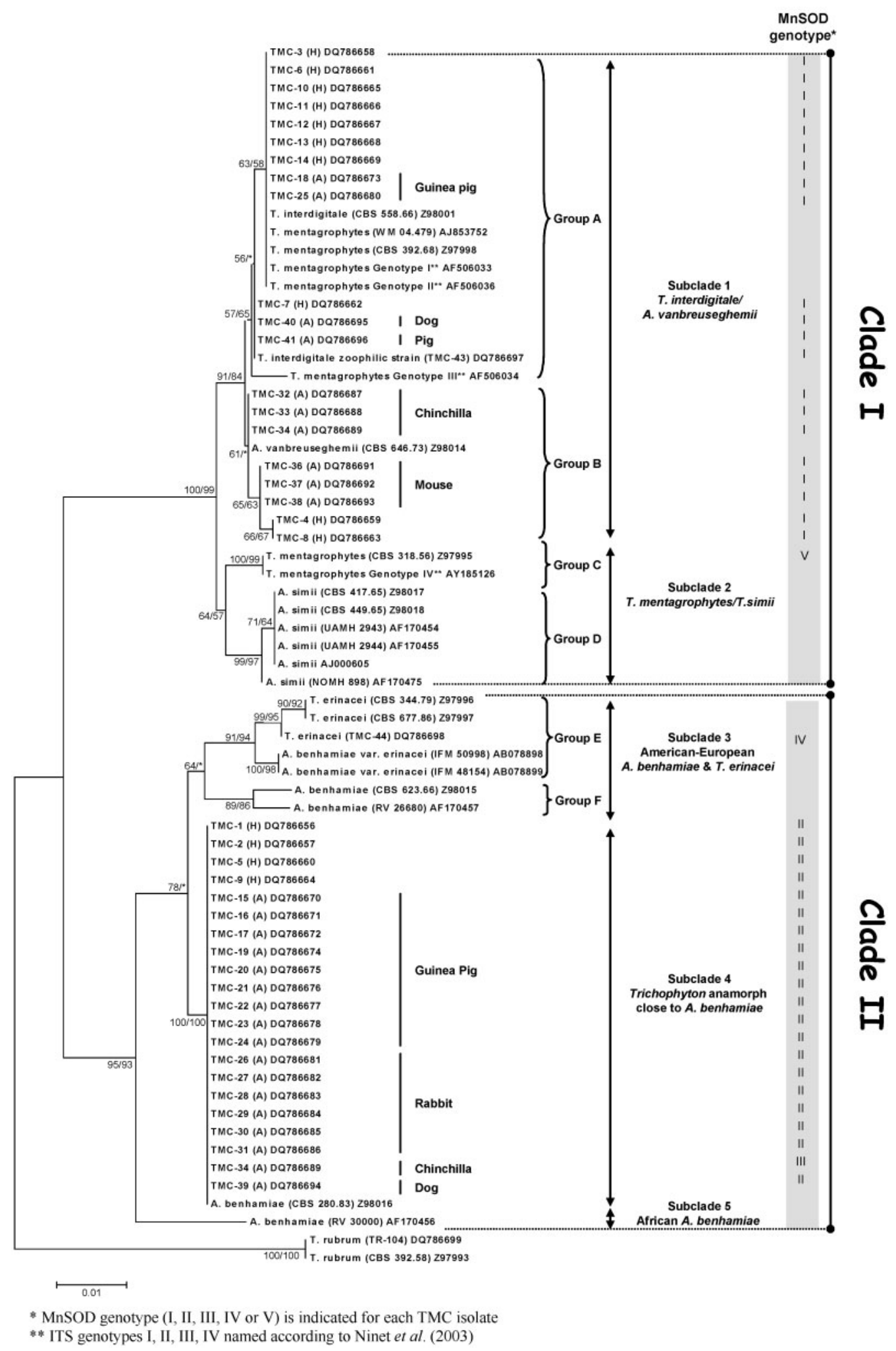

genes were used: Ninet et al. (2003) were able to distinguish three T. mentagrophytes genotypes on the basis of two $28 \mathrm{~S}$ rDNA polymorphic sites, and Kano et al. $(1998,2003)$ were able to identify dermatophyte species with high sequence identity (99\%) between reference strains and clinical isolates using a chitin synthase 1 based PCR assay. 
Fig. 1. Rooted NJ tree of the T. mentagrophytes complex inferred from ITS sequences. T. rubrum served as an outgroup. ITS sequence accession numbers are given after each strain number. Bootstrap NJ and ML values are given as percentages near the individual nodes; values of $<50 \%$ are shown as *. The evolutionary distances between organisms are indicated by the horizontal branch lengths (scale bar: 0.01 substitutions per base pair), which reflect the number of nucleotide substitutions per site along the branches from node to end point. The percentages of bootstrap samplings supporting the interior branches are noted. MnSOD sequence accession numbers are: DQ786700 to DQ786740 for isolates TMC-1 to TMC-41, DQ786741 for the $T$. interdigitale standard strain (TMC-42), DQ786742 for the zoophilic strain of $T$. interdigitale (TMC-43), DQ786743 for the T. erinacei standard strain (TMC-44), EF614237 for T. mentagrophytes strain CBS 318.56, and DQ786744 for T. rubrum clinical isolate TR-104. For each TMC isolate, the corresponding MnSOD genotype (I, II, III, IV or V) is indicated on the right.

Similarly to the previously described $15 \%$ variation at the ITS region locus within the T. mentagrophytes complex (Graser et al., 1999a), ITS sequences from our isolates and standard strains reached up to $10.6 \%$ divergence, and fell into two clades. Clade I was composed of two subclades (Fig. 1). Subclade 1 included T. interdigitale CBS 558.66 (close to the T. interdigitale neotype described by Graser et al., 1999b), the zoophilic T. interdigitale strain TMC-43 and $A$. vanbreuseghemii CBS 646.73, and corresponded to the ' $T$. interdigitale/A. vanbreuseghemii' subclade. Interestingly, isolates within this subclade showed high variability, yielding a subdivision into two main groups: group $\mathrm{A}$, with species closer to $T$. interdigitale neotype, and group $B$, a mainly zoophilic cluster, which also contained $A$. vanbreuseghemii CBS 646.73. In subclade 2, the T. mentagrophytes neotype CBS 318.56 (group C) was closer to A. simii (group D), as previously described (Graser et al., 1999b). Clustering of the T. mentagrophytes neotype and A. simii within clade I suggested that the T. mentagrophytes neotype is closer to $T$. interdigitale than to T. erinacei, in accordance with previous data (Graser et al., 1999b). Clade II contained all A. benhamiae/T. erinacei database sequences (subclades 3,4 and 5). As previously described (Makimura et al., 1998; Summerbell et al., 1999), ITS sequence analysis clearly distinguished the American-European from the African A. benhamiae, which was on a separate branch (subclade 5). The T. erinacei/American-European A. benhamiae subclade (subclade 3) contained two groups: group E, which included only $T$. erinacei isolates [our $T$. erinacei standard strain TMC-44; A. benhamiae IFM 50998 and IFM 48154 are T. erinacei strains, isolated from hedgehog (Takahashi et al., 2003)], and group $\mathrm{F}$, the American-European A. benhamiae. Regarding the recent study of Takahashi et al. (2003), which confirmed morphological, physiological and genetic similarity among the hedgehog-borne isolates, forming a distinct mating group from American-European and from African races of $A$. benhamiae (none or partial fertility), group $\mathrm{E}$ corresponded to those hedgehog-borne isolates belonging to an independent variety which should be identified as 'A. benhamiae var. erinacei' (Takahashi et al., 2003). All our human and animal isolates ITS sequences belonging to clade II showed low variability and clustered in the 'Trichophyton anamorph close to A. benhamiae' subclade (subclade 4, Fig. 1).

\section{Correlation between TMC isolate distribution and host species/morphology/clinical pattern}

TMC isolates were related either to T. interdigitale/A. vanbreuseghemii (clade I, subclade 1) or to 'Trichophyton anamorph close to A. benhamiae' (clade II, subclade 4); none clustered with the T. mentagrophytes neotype (clade I, subclade 2), or with $T$. erinacei (clade II, subclade 3 ), except for our T. erinacei standard strain TMC-44. Within

Table 2. Position of the polymorphic sites on the alignment of T. mentagrophytes MnSOD partial nucleotide and protein sequences

The 'genotype I' sequence was found in T. mentagrophytes clinical isolates TMC-3, 4, 6-8, 10-14, 18, 25, 32, 33, 35-38, 40 and 41, the T. interdigitale standard strain (TMC-42) and the zoophilic strain of T. interdigitale (TMC-43). The 'genotype II' sequence was found in T. mentagrophytes clinical isolates TMC-1, 2, 5, 9, 15-17, 19-24, 26-31 and 39. The 'genotype III' sequence was found in T. mentagrophytes clinical isolate TMC-34. The 'genotype IV' sequence was found in the T. erinacei (TMC-44) standard strain. The 'genotype V' sequence was found in the T. mentagrophytes neotype (CBS 318.56). These five genotypes resulted in only two deduced amino acid sequences: type I (genotype I) and type II (genotypes II, III, IV and V). Positions are numbered according to the numbering of MnSOD nucleotide sequences deposited in the GenBank database. Polymorphic sites in the intron (positions 316-374) are highlighted in bold italic.

\begin{tabular}{|c|c|c|c|c|c|c|c|c|c|c|c|c|c|c|c|c|c|c|c|c|c|c|c|c|c|c|c|c|c|}
\hline & 3 & 51 & 54 & 87 & 93 & 129 & 132 & 144 & 189 & 195 & 201 & $208^{\star}$ & 255 & 268 & $285^{\star}$ & 300 & 322 & 326 & 330 & 334 & 349 & 351 & 352 & 355 & 358 & 360 & 368 & 370 & 386 \\
\hline I & $\mathrm{T}$ & $\mathrm{T}$ & G & A & C & $\mathrm{T}$ & G & $\mathrm{T}$ & G & $\mathrm{T}$ & G & $\mathrm{T}$ & $\mathrm{T}$ & $\mathrm{T}$ & $\mathrm{T}$ & A & $T$ & $A$ & $C$ & $A$ & $A$ & $T$ & $G$ & $G$ & $G$ & $A$ & - & $G$ & $\mathrm{~T}$ \\
\hline II & $\mathrm{C}$ & $\mathrm{C}$ & G & A & $\mathrm{T}$ & C & $\mathrm{T}$ & C & A & $\mathrm{C}$ & $\mathrm{T}$ & C & C & C & G & G & $T$ & $A$ & $T$ & $C$ & $G$ & $T$ & G & $G$ & $T$ & $T$ & $C$ & $A$ & C \\
\hline IV & $\mathrm{C}$ & C & A & A & $\mathrm{T}$ & $\mathrm{T}$ & $\mathrm{T}$ & C & A & $\mathrm{T}$ & $\mathrm{T}$ & C & C & $\mathrm{T}$ & G & G & $T$ & $G$ & $T$ & C & $G$ & $T$ & $A$ & G & $A$ & $T$ & $C$ & $A$ & $\mathrm{~T}$ \\
\hline $\mathrm{V}$ & $\mathrm{T}$ & C & $\mathrm{G}$ & $\mathrm{T}$ & C & C & $\mathrm{T}$ & $\mathrm{T}$ & G & $\mathrm{T}$ & $\mathrm{T}$ & C & C & $\mathrm{T}$ & G & $\mathrm{G}$ & $C$ & $G$ & $A$ & $A$ & $G$ & $A$ & $G$ & $A$ & $G$ & $G$ & - & $A$ & $\mathrm{~T}$ \\
\hline
\end{tabular}

${ }^{*}$ Non-synonymous mutations yielding amino acid mutation at positions 70 and 95 of the MnSOD protein sequence. Type I (genotype I sequences): $\mathrm{Ser}^{70}$, Pro ${ }^{95}$. Type II (genotype II, III, IV and V sequences): $\mathrm{His}^{70}, \mathrm{Gln}^{95}$. 
subclade 1, isolates remained clustered with respect to host species. Most human TMC isolates were closer to the $T$. interdigitale neotype, in group $\mathrm{A}$, which also contained four animal isolates from both natural hosts (two from guinea pig, close to the $T$. interdigitale neotype) and occasional hosts (one from a dog and one from a pig, closer to the zoophilic strain of $T$. interdigitale TMC-43). In group B, which was mainly zoophilic, TMC isolates from the same host clustered together, forming three distinct subgroups: chinchilla, mouse and human. The zoophilic strains of $T$. interdigitale (group B) were linked to A. vanbreuseghemii, confirming Takashio's mating-type studies, where some isolates derived from mice and chinchillas were shown to be able to mate with A. vanbreuseghemii (Takashio, 1973). Clade II zoophilic isolates were mostly derived from rabbits and guinea pigs, which are known to be natural hosts of the Trichophyton anamorph of A. benhamiae, whereas the natural host of $T$. erinacei is the hedgehog (Summerbell et al., 2002; Weitzman \& Summerbell, 1995). Analysis of animal TMC isolate distribution showed that only isolates from mouse and rabbit (natural hosts of the T. mentagrophytes species complex) clustered specifically within subclades 1 and 4, respectively. Other natural hosts (guinea pig and chinchilla) were represented in both subclades, but most chinchilla isolates (3/4) were closer to $T$. interdigitale (subclade 1) whereas most guinea pig ones (9/11) were closer to the Trichophyton anamorph of A. benhamiae (subclade 4). Occasional hosts (dog and pig) were also in both subclades. Taken as a whole, this distribution reflects the classical association of $A$. vanbreuseghemii with mice and chinchillas, and of $A$. benhamiae with rabbits and guinea pigs (Summerbell et al., 2002), but it also highlights the complexity of the adaptation and evolution of the $T$. mentagrophytes species complex at the molecular level.

At the clinical level, there was a good correlation between the anamorph diversity based on morphology or clinical pattern, and the genotype. The morphology of subclade 1 human and animal TMC isolates was similar to the $T$. interdigitale/A.vanbreuseghemii phenotype (Table 1). Most colonies had a soft to downy texture with yellow-orange to brown reverse, associated with subspherical conidia, quite often spiral hyphae, and occasionally macroconidia. All human TMC isolates with $T$. interdigitale phenotypic features fell in this first clade, close to $T$. interdigitale, whereas TMC isolates closer to $T$. erinacei and $A$. benhamiae exhibited a different phenotype: mostly clavate or subspherical to ovoid microconidia, mycelium branchlets at right angles, no spiral hyphae (TMC-1, TMC-2, TMC-5 and TMC-9 in Table 1), and clustered with animal TMC isolates included in clade II (Fig. 1). Our results fitted well with the known predilection of dermatophyte species for certain body areas (De Hoog et al., 1998; Fumeaux et al., 2004; Graser et al., 1998, 1999a, b; Kardjeva et al., 2006; Ninet et al., 2003; Summerbell et al., 2002; Weitzman \& Summerbell, 1995). Clade I human isolates (TMC-3, TMC6, TMC-11, TMC-12, TMC-13 and TMC-14 in Table 1) were isolated from tinea pedis, like the neotype of $T$. interdigitale, or from tinea unguium, whereas clade II human isolates (TMC-1, TMC-2, TMC-5 and TMC-9 in Table 1) were mostly associated with inflammatory lesions at body sites other than the feet, clustering with isolates from rabbits and guinea pigs which, as currently popular pets, might contribute to the increase of $A$. benhamiaerelated Trichophyton strains isolated at present in France. A similar increase was recently reported in Japan and in Switzerland, where the introduction of unusual pets (in particular guinea pigs and rabbits) has been linked to the recent appearance of $A$. benhamiae (Fumeaux et al., 2004; Kano et al., 1998; Mochizuki et al., 2001). Isolates TMC-4 and TMC-8 (group B, Fig. 1), which were isolated from inflammatory tinea corporis, were closer to rodent isolates (chinchilla or mouse), supporting the zoophilic origin of these T. interdigitale isolates. Within clade II, most isolates were derived from animals and clustered with the Trichophyton anamorph of $A$. benhamiae. Such taxa are generally encountered as zoophilic in France, Belgium and Spain, where they are expected to provoke acute inflammatory infections in human beings, but they can also be encountered as 'T. interdigitale-like' in North America and Eastern Europe (Summerbell et al., 2002). Here, the clinical features reported for our French human clade II isolates fit well with the zoophilic phenotype (Table 1) and confirm these data.

\section{Conclusions}

Phylogenetic analysis of French $T$. mentagrophytes complex isolates: contribution to a better understanding of the relationships between human and animal isolates. This phylogenetic analysis of T. mentagrophytes complex included both human (14) and animal (27) isolates from a wide range of occasional and natural hosts. Our data are consistent with previous findings (De Hoog et al., 1998; Faggi et al., 2001; Graser et al., 1999b; Kano et al., 1998; Makimura et al., 1998; Mochizuki et al., 1990, 1996, 2001), confirming the close relationship between $T$. interdigitale/A. vanbreuseghemii and the T. mentagrophytes neotype, separate from T. erinaceilA. benhamiae, which seems to be primarily zoophilic (Graser et al., 1999b; Kano et al., 1998; Mochizuki et al., 2001). Our TMC isolates clustered either with T. interdigitale/A. vanbreuseghemii or with the Trichophyton anamorph of $A$. benhamiae, but not with $T$. mentagrophytes neotype or T. erinacei. Mouse and rabbit isolates clustered specifically in clades I and II, respectively, but we did not find a systematic association between specific genotypes of $T$. mentagrophytes complex isolates and human or animal hosts, either natural (guinea pig or chinchilla) or occasional (dog or pig). This association had some morphological profile translations, since morphological features were mostly similar within isolates of the same clade. Microscopic features were more contributive than macroscopic ones, making them useful as indicators for routine morphological identification. They included the shape of the microconidia, previously described as a criterion to distinguish $A$. vanbreuseghemii- and A. benhamiae-related isolates (Graser et al., 1999a). However, morphology was not always 
characteristic and stable, and, therefore, not totally reliable, as previously described (Nenoff et al., 2007). Thus, further molecular and morphological studies are needed.

In terms of evolution and host adaptation, our phylogenetic analysis supports the hypothesis of a recent divergence of $T$. interdigitale/A. vanbreuseghemii. As previously suggested (Makimura et al., 1998; Mochizuki et al., 1996), T. interdigitale could be the most anthropophilic Trichophyton species of this complex, representing a degenerate anamorph of $A$. vanbreuseghemii, having lost its mating ability and becoming a clonal population when it develops in the human host, like T. rubrum (Graser et al., 2006).

The value of MnSOD and ITS for genotyping and phylogenetic analysis of the $T$. mentagrophytes complex. In terms of molecular approach, genotyping of dermatophyte strains has a number of potential epidemiological and clinical applications. As fungal species causing dermatophytosis can only be identified in 2-3 weeks after a positive culture, a rapid PCR method should be helpful in defining prevention and therapeutic strategies (Fernandez-Torres et al., 2003; Kardjeva et al., 2006; Mock et al., 1998). The T. mentagrophytes MnSOD and ITS genes were targeted in order to improve the laboratory identification of dermatophytes. Although the results at the MnSOD locus confirmed the genetic heterogeneity of the T. mentagrophytes complex, they revealed a lower degree of diversity (similar to that of 28S rRNA: Ninet et al., 2003) than the variable ITS locus. In particular, in clade I, all TMC isolates clustered in 'MnSOD genotype I', whereas five ITS genotypes could be differentiated for the same isolates. This probably results from the recent evolutionary dispersion of the anthropophilic dermatophytes, where some genes (e.g. coding for morphological or physiological characters) have rapidly fixed mutations, whereas housekeeping genes (such as MnSOD) have undergone relatively low fixation of mutations (Gupta et al., 2002). However, the MnSOD gene clearly differentiated the four $T$. mentagrophytes complex species ( $T$. interdigitale/A. vanbreuseghemii, T. mentagrophytes, T. erinacei and other A. benhamiae isolates) and $T$. rubrum, making it relevant as part of a multi-locus sequence typing approach (Devulder et al., 2005).

On the other hand, comparison of the ITS region was suitable not only for phylogeny but also for species identification of dermatophytes, a critical requirement for applying appropriate treatment and preventive measures against dermatophytosis. An early determination of the anthropophilic or zoophilic character of the agent could lead to an earlier identification of the infection source (human, animal or soil), and therefore help in setting up suitable prevention and treatment measures.

Further, besides the current gold standard procedure based on direct microscopy of $\mathrm{KOH}$ preparations, combined with fungal culture, molecular identification of dermatophytes may help to identify fungal isolates that are not growing or that display unusual morphology. The recent development of procedures to isolate DNA directly from clinical specimens (skin, hair or nails) would further enhance the potential of PCR in the clinical mycology laboratory, decreasing false-negative culture results $(15 \%)$ and the misidentification (6\%) of dermatophyte species (Kano et al., 2003; Kardjeva et al., 2006). In addition, contrary to usual belief, sequencing of the ITS locus is not much more expensive than identifying dermatophyte species by conventional methods (Kardjeva et al., 2006). To summarize, molecular identification such as ITS sequencing could become part of the diagnostic gold standard for dermatophytosis, especially in reference laboratories with pre-existing molecular facilities.

\section{ACKNOWLEDGEMENTS}

We are grateful to Christophe Noël (School of Biology, Institute for Research on Environment and Sustainability, Devonshire Building, University of Newcastle upon Tyne, UK) for critical review of the phylogenetic part of the manuscript, and to the Pasteur Institute of Paris Mycology Department for confirming the identification of standard strains. This work was supported by the French Ministry of Research (EA3609), and Lille 2 University. It was presented as a poster to the ISHAM meeting, Paris, France, 25-29 June 2006.

\section{REFERENCES}

Contet-Audonneau, N., Davril, A., Hanesse, B., Kuntz, C., Schmutz, J. L. \& Percebois, G. (2001). Prévalence des dermatophyties des pieds chez le sujet sain: résultats d'une enquête dans un centre de médecine préventive. J Mycol Med 11, 135-141.

Davison, F. D. \& Mackenzie, D. W. (1984). DNA homology studies in the taxonomy of dermatophytes. Sabouraudia 22, 117-123.

Davison, F. D., Mackenzie, D. W. \& Owen, R. J. (1980). Deoxyribonucleic acid base compositions of dermatophytes. J Gen Microbiol 118, 465-470.

De Hoog, G. S., Bowman, B., Graser, Y., Haase, G., El Fari, M., Gerrits van den Ende, A. H., Melzer-Krick, B. \& Untereiner, W. A. (1998). Molecular phylogeny and taxonomy of medically important fungi. Med Mycol 36 (Suppl. 1), 52-56.

Denis, C. M., Mazars, E., Guyot, K., Odberg-Ferragut, C., Viscogliosi, E., Dei-Cas, E. \& Wakefield, A. E. (2000). Genetic divergence at the SODA locus of six different formae speciales of Pneumocystis carinii. Med Mycol 38, 289-300.

Devulder, G., Perouse de Montclos, M. \& Flandrois, J. P. (2005). A multigene approach to phylogenetic analysis using the genus Mycobacterium as a model. Int J Syst Evol Microbiol 55, 293-302.

Faggi, E., Pini, G., Campisi, E., Bertellini, C., Difonzo, E. \& Mancianti, F. (2001). Application of PCR to distinguish common species of dermatophytes. J Clin Microbiol 39, 3382-3385.

Faggi, E., Pini, G. \& Campisi, E. (2002). PCR fingerprinting for identification of common species of dermatophytes. J Clin Microbiol 40, 4804-4805.

Felsenstein, J. (1997). An alternating least squares approach to inferring phylogenies from pairwise distances. Syst Biol 46, 101-111.

Fernandez-Torres, B., Inza, I. \& Guarro, J. (2003). In vitro activities of the new antifungal drug eberconazole and three other topical 
agents against 200 strains of dermatophytes. J Clin Microbiol 41, 5209-5211.

Fréalle, E., Noel, C., Viscogliosi, E., Camus, D., Dei-Cas, E. \& Delhaes, L. (2005). Manganese superoxide dismutase in pathogenic fungi: an issue with pathophysiological and phylogenetic involvements. FEMS Immunol Med Microbiol 45, 411-422.

Fréalle, E., Noel, C., Nolard, N., Symoens, F., Felipe, M.-S., Dei-Cas, E., Camus, D., Viscogliosi, E. \& Delhaes, L. (2006). Manganese superoxide dismutase based phylogeny of pathogenic fungi. Mol Phylogenet Evol $41,28-39$.

Fumeaux, J., Mock, M., Ninet, B., Jan, I., Bontems, O., Léchenne, B., Lew, D., Panizzon, R. G., Jousson, O. \& Monod, M. (2004). First report of Arthroderma benhamiae in Switzerland. Dermatology 208, 244-250.

Graser, Y., el Fari, M., Presber, W., Sterry, W. \& Tietz, H. J. (1998). Identification of common dermatophytes (Trichophyton, Microsporum, Epidermophyton) using polymerase chain reactions. $\mathrm{Br} J$ Dermatol 138, 576-582.

Graser, Y., El Fari, M., Vilgalys, R., Kuijpers, A. F., De Hoog, G. S., Presber, W. \& Tietz, H. (1999a). Phylogeny and taxonomy of the family Arthrodermataceae (dermatophytes) using sequence analysis of the ribosomal ITS region. Med Mycol 37, 105-114.

Graser, Y., Kuijpers, A. F., Presber, W. \& De Hoog, G. S. (1999b). Molecular taxonomy of Trichophyton mentagrophytes and T. tonsurans. Med Mycol 37, 315-330.

Graser, Y., De Hoog, S. \& Summerbell, R. C. (2006). Dermatophytes: recognizing species of clonal fungi. Med Mycol 44, 199-209.

Gupta, A. K., Kohli, Y. \& Summerbell, R. C. (2002). Exploratory study of single-copy genes and ribosomal intergenic spacers for distinction of dermatophytes. Stud Mycol 47, 87-96.

Harmsen, D., Schwinn, A., Weig, M., Brocker, E. B. \& Heesemann, J. (1995). Phylogeny and dating of some pathogenic keratinophilic fungi using small subunit ribosomal RNA. J Med Vet Mycol 33, 299-303.

Jousson, O., Lechenne, B., Bontems, O., Capoccia, S., Mignon, B., Barblan, J., Quadroni, M. \& Monod, M. (2004). Multiplication of an ancestral gene encoding secreted fungalysin preceded species differentiation in the dermatophytes Trichophyton and Microsporum. Microbiology 150, 301-310.

Kac, G., Bougnoux, M. E., Feuilhade De Chauvin, M., Sene, S. \& Derouin, F. (1999). Genetic diversity among Trichophyton mentagrophytes isolates using random amplified polymorphic DNA method. Br J Dermatol 140, 839-844.

Kano, R., Nakamura, Y., Watari, T., Watanabe, S., Takahashi, H., Tsujimoto, H. \& Hasegawa, A. (1998). Molecular analysis of chitin synthase 1 (CHS1) gene sequences of Trichophyton mentagrophytes complex and T. rubrum. Curr Microbiol 37, 236-239.

Kano, R., Hirai, A., Muranatsu, M., Watari, T. \& Hasegawa, A. (2003). Direct detection of dermatophytes in skin samples based on sequences of the chitin synthase 1 (CHS1) gene. J Vet Med Sci 65, 267-270.

Kardjeva, V., Summerbell, R., Kantardjiev, T., DevliotouPanagiotidou, D., Sotiriou, E. \& Graser, Y. (2006). Forty-eight-hour diagnosis of onychomycosis with subtyping of Trichophyton rubrum strains. J Clin Microbiol 44, 1419-1427.

Kaufman, G., Horwitz, B. A., Hadar, R., Ullmann, Y. \& Berdicevsky, I. (2004). Green fluorescent protein (GFP) as a vital marker for pathogenic development of the dermatophyte Trichophyton mentagrophytes. Microbiology 150, 2785-2790.

Liu, D., Coloe, S., Baird, R. \& Pedersen, J. (1997). PCR identification of Trichophyton mentagrophytes var. interdigitale and T. mentagrophytes var. mentagrophytes dermatophytes with a random primer. J Med Microbiol 46, 1043-1046.
Liu, D., Coloe, S., Baird, R. \& Pedersen, J. (2000). Application of PCR to the identification of dermatophyte fungi. J Med Microbiol 49, 493-497.

Makimura, K., Mochizuki, T., Hasegawa, A., Uchida, K., Saito, H. \& Yamaguchi, H. (1998). Phylogenetic classification of Trichophyton mentagrophytes complex strains based on DNA sequences of nuclear ribosomal internal transcribed spacer 1 regions. J Clin Microbiol 36, 2629-2633.

Makimura, K., Tamura, Y., Mochizuki, T., Hasegawa, A., Tajiri, Y., Hanazawa, R., Uchida, K., Saito, H. \& Yamaguchi, H. (1999). Phylogenetic classification and species identification of dermatophyte strains based on DNA sequences of nuclear ribosomal internal transcribed spacer 1 regions. J Clin Microbiol 37, 920-924.

Mochizuki, T., Takada, K., Watanabe, S., Kawasaki, M. \& Ishizaki, H. (1990). Taxonomy of Trichophyton interdigitale (Trichophyton mentagrophytes var. interdigitale) by restriction enzyme analysis of mitochondrial DNA. J Med Vet Mycol 28, 191-196.

Mochizuki, T., Watanabe, S. \& Uehara, M. (1996). Genetic homogeneity of Trichophyton mentagrophytes var. interdigitale isolated from geographically distant regions. J Med Vet Mycol 34, 139-143.

Mochizuki, T., Sugie, N. \& Uehara, M. (1997). Random amplification of polymorphic DNA is useful for the differentiation of several anthropophilic dermatophytes. Mycoses 40, 405-409.

Mochizuki, T., Kawasaki, M., Ishizaki, H. \& Makimura, K. (1999). Identification of several clinical isolates of dermatophytes based on the nucleotide sequence of internal transcribed spacer 1 (ITS 1) in nuclear ribosomal DNA. J Dermatol 26, 276-281.

Mochizuki, T., Kawasaki, M., Ishizaki, H., Kano, R., Hasegawa, A., Tosaki, H. \& Fujihiro, M. (2001). Molecular epidemiology of Arthroderma benhamiae, an emerging pathogen of dermatophytoses in Japan, by polymorphisms of the non-transcribed spacer region of the ribosomal DNA. J Dermatol Sci 27, 14-20.

Mochizuki, T., Ishizaki, H., Barton, R. C., Moore, M. K., Jackson, C. J., Kelly, S. L. \& Evans, E. G. (2003). Restriction fragment length polymorphism analysis of ribosomal DNA intergenic regions is useful for differentiating strains of Trichophyton mentagrophytes. J Clin Microbiol 41, 4583-4588.

Mock, M., Monod, M., Baudraz-Rosselet, F. \& Panizzon, R. G. (1998). Tinea capitis dermatophytes: susceptibility to antifungal drugs tested in vitro and in vivo. Dermatology 197, 361-367.

Monod, M., Jaccoud, S., Zaugg, C., Lechenne, B., Baudraz, F. \& Panizzon, R. (2002). Survey of dermatophyte infections in the Lausanne area Switzerland. Dermatology 205, 201-203.

Nenoff, P., Herrmann, J. \& Graser, Y. (2007). Trichophyton mentagrophytes sive interdigitale? A dermatophyte in the course of time. J Dtsch Dermatol Ges 5, 198-202.

Ninet, B., Jan, I., Bontems, O., Lechenne, B., Jousson, O., Panizzon, R., Lew, D. \& Monod, M. (2003). Identification of dermatophyte species by 28 S ribosomal DNA sequencing with a commercial kit. J Clin Microbiol 41, 826-830.

Nowicki, R., Szarmach, H. \& Sadowska, E. (1994). Mycotic infections in studies of Gdansk clinic of dermatology in years 1984-1992. J Mycol Med 4, 168-171.

Page, R. D. (1996). TreeView: an application to display phylogenetic trees on personal computers. Comput Appl Biosci 12, 357-358.

Parker, M. W. \& Blake, C. C. (1988). Iron- and manganese-containing superoxide dismutases can be distinguished by analysis of their primary structures. FEBS Lett 229, 377-382.

Parker, R. \& Patterson, B. (1987). Architecture of fungal introns: implications for spliceosome assembly. In Molecular Biology of RNA: New Perspectives, pp. 133-150. Edited by M. Inouye \& B. Dubock. New York: Academic Press. 
Probst, S., De Hoog, G. S. \& Gräser, Y. (2002). Development of DNA markers to explore host shifts in dermatophytes. Stud Mycol 47, 57-74.

Summerbell, R. C., Haugland, R. A., Li, A. \& Gupta, A. K. (1999). rRNA gene internal transcribed spacer 1 and 2 sequences of asexual, anthropophilic dermatophytes related to Trichophyton rubrum. J Clin Microbiol 37, 4005-4011.

Summerbell, R. C., Weitzman, I. \& Padhye, A. (2002). The Trichophyton mentagrophytes complex: biological species and mating type prevalences of North American isolates, and a review of the worldwide distribution and host associations of species and mating types. Stud Mycol 47, 75-86.

Takahashi, Y., Sano, A., Takizawa, K., Fukushima, K., Miyaji, M. \& Nishimura, K. (2003). The epidemiology and mating behavior of
Arthroderma benhamiae var. erinacei in household four-toed hedgehogs (Atelerix albiventris) in Japan. Nippon Ishinkin Gakkai Zasshi 44, $31-38$.

Takashio, M. (1973). Une nouvelle forme sexuée du complexe Trichophyton menagrophytes, Arthroderma vanbreuseghemii, sp. nov. Ann Parasitol Hum Comp 48, 713-732.

Tippmann, H. F. (2004). Analysis for free: comparing programs for sequence analysis. Brief Bioinform 5, 82-87.

Weitzman, I. \& Summerbell, R. C. (1995). The dermatophytes. Clin Microbiol Rev 8, 240-259.

Edited by: D. Sanglard 